\title{
Coastal evolution of a Holocene barrier spit [Bug peninsula/NW- Rügen] deduced from geological structure and relative sea-level
}

\author{
Michael Naumann, Reinhard Lampe, Gösta Hoffmann
}

Abstract:

The Bug peninsula/NW Rügen located at the south-western Baltic coast has been investigated to study coastal barrier evolution depending on Holocene sea-level rise. In this so far minor explored coastal section 25 sediment cores, seven ground-penetrating radar tracks and six sediment-echosounder tracks were collected from which six depositional facies types were derived. The data show that the recent peninsula consists of an about $10 \mathrm{~m}$ thick Holocene sediment sequence, underlain by Pleistocene till or (glaci-) fluviolimnic fine sand. Although no absolute age data could be gathered to estimate the chronostratigraphy of the sedimentary sequence the relation of the depositional facies to the local relative sea-level curve allow the reconstruction of the palaeogeographic evolution of the Bug barrier spit.

The marine inundation of the area occurred around 7,000 BC during the Littorina transgression. In this stage the sea level rose rapidly and generated a fast increasing subaquatic accommodation space, where fine clastic material was deposited nearly or below the wave base and levelled the former relief. Accumulative coastal landforms grew to only minor extent because the accommodation space increased faster than it was filled with material from neighbouring eroding cliffs. Since the time the sea-level rise decreased accumulation became more dominant and the main barrier was built up in only some two thousand years. According to the beach ridge formations visible on the barrier's surface the shoreline development of the Bug peninsula can be divided into two evolutionary stages depending on wave impact, erosion and overwash.

Today, the barrier displays a volume of 66.4 million $\mathrm{m}^{3}$ according to a feeder cliff retreat of at about $2000 \mathrm{~m}$. Although the barrier seems to be in maturity stage some features points to instability. Coastal protection measures in the north prevent breakthrough and detachment. Waterway dredging in the south inhibited further elongation and accretion with spits growing from Hiddensee. Without these measures the barrier would disintegrate and be reshaped by inlet generation and increasing erosion in the north and inlet closure and beach progradation in the south.

[Küstenentwicklung einer holozänen Nehrung [Halbinsel Bug/NW-Rügen] abgeleitet aus der geologischen Struktur und dem relativen Meeresspiegel]

Kurzfassung:

Die an der südwestlichen Ostseeküste gelegene Halbinsel Bug/NW Rügen wurde untersucht, um die Entwicklung von Haken und Nehrungen unter dem Einfluss des holozänen Meeresspiegelanstiegs zu studieren. Als Datengrundlage dienten 25 Sedimentkerne, sowie sieben Georadar- und sechs Sedimentecholotprofile, aus denen sechs Lithofaziestypen abgeleitet wurden. Danach besteht die Nehrung aus einer durchschnittlich 10 m mächtigen holozänen Sedimentfolge, die auf pleistozäner Basis aus Geschiebemergel und (glazi-)fluviolimnischen Feinsanden lagert. Obwohl keine absoluten Altersdaten gewonnen wurden, kann die Sedimentabfolge mit der lokalen relativen Meeresspiegelkurve problemlos korreliert und eine Modellvorstellung für die Nehrungsentwicklung geschlussfolgert werden.

Die marine Inundation des Untersuchungsgebietes erfolgte um 7.000 BC während der Littorina-Transgression. In diesem Stadium stieg der Meeresspiegel rapide an and generierte einen schnell wachsenden Akkumulationsraum, in dem feinklastisches Material an oder unter der Wellenbasis akkumulierte und zu einem Reliefausgleich beitrug. Akkumulative Küstenformen bildeten sich nur in geringem Maße, da der Akkumulationsraum schneller wuchs als er durch das aus der Küstenerosion stammende Material aufgefüllt werden konnte. In dem Maße, indem der Meeresspiegelanstieg sich verlangsamte, gewann die Akkumulation an Bedeutung und der Hauptteil der Nehrung wurde innerhalb von rund zweitausend Jahren landfest. Entsprechend dem Verlauf von Strandwällen auf seiner heutigen Oberfläche lassen sich zwei Entwicklungsphasen aushalten, die von unterschiedlichen wellenenergetischen, erosiven und overwash-Prozessen bestimmt werden.

Gegenwärtig besitzt die Nehrung ein Volumen von $66,4 \mathrm{Mio} \mathrm{m}^{3}$, woraus sich auf einen Rückgang des benachbarten Kliffs von rund $2000 \mathrm{~m}$ schließen lässt. Obwohl die Nehrung entwicklungsmäßig in ihrem Reifestadium angelangt zu sein scheint, deuten einige Merkmale auf zunehmende Instabilität hin. Im nördlichen Bereich verhindern Küstenschutzmaßnahmen einen Nehrungsdurchbruch und beginnende Auflösung. Im Süden haben Fahrwasserbaggerungen eine weitere Längenzunahme und das Zusammenwachsen mit Haken von Hiddensee verhindert. Ohne diese Maßnahmen würde die Nehrung durch Seegattbildung und zunehmende Erosion im Norden und Seegattschließung und zunehmende Uferprogradation im Süden eine neue Gestalt annehmen.

Key words:

Baltic Sea, Rügen, Holocene, sea-level rise, coastal evolution, barrier, lagoon

Adresses of authors: M. Naumann, Baltic Sea Research Institute Warnemünde, Seestraße 15, 18119 Rostock-Warnemünde, Germany. E-Mail: michaelnaumann@io-warnemünde.de; R. Lampe, Institute of Geography and Geology, University of Greifswald, Jahnstraße 16, 17487 Greifswald, Germany; G. Hoffmann, Applied Geosciences Dept., German University of Oman, PO BOX 1816, Athaibah, PC 130, Sultanate of Oman 


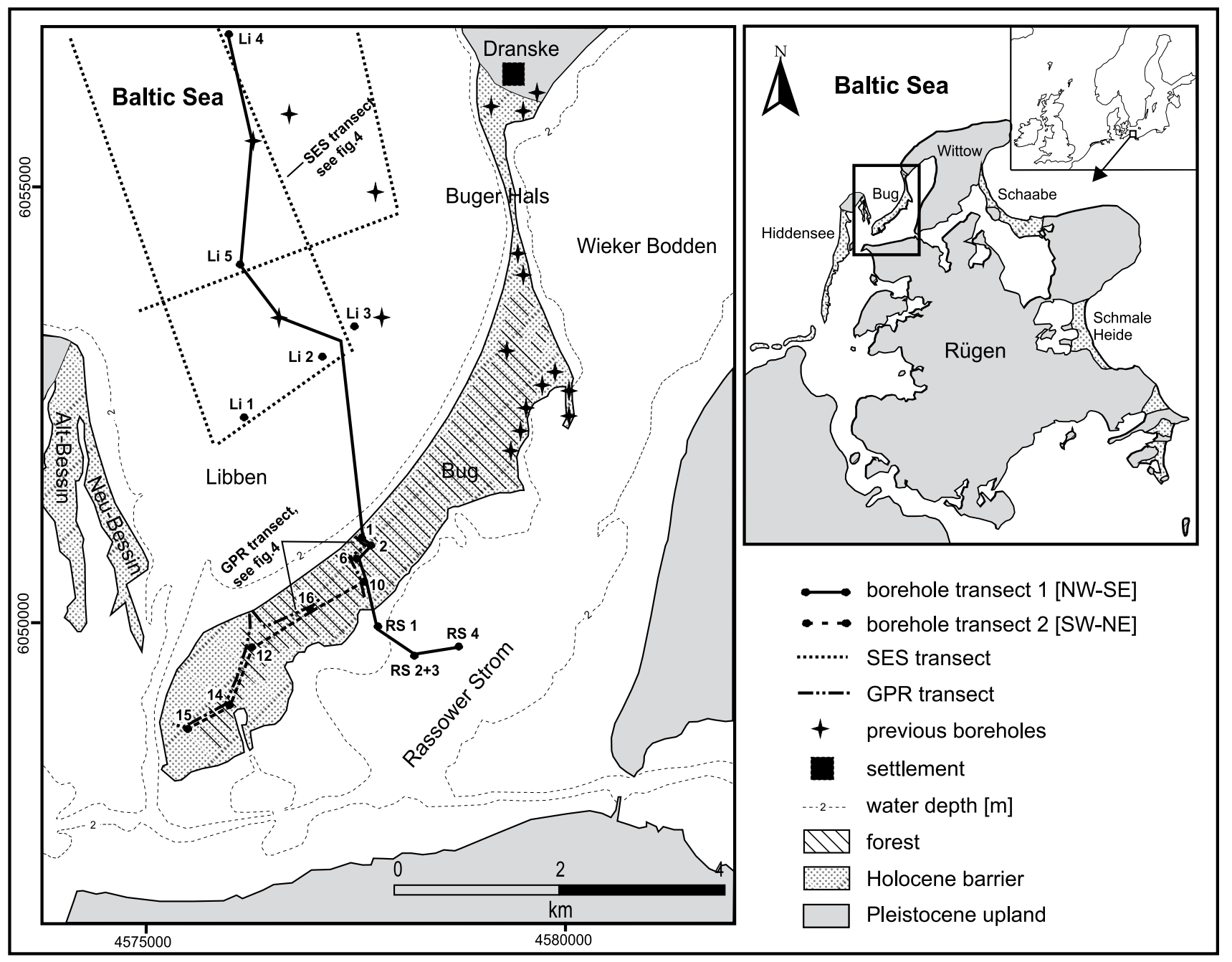

Fig. 1: Map of the study area and sites of boreholes and transects. / Abb. 1: Karte des Untersuchungsgebietes und Lage der Bohrungen und Transekte.

\section{Introduction and aims}

The succeeding presentation is thematically integrated in the "Sinking Coasts"-project (SINCOS) in which the interactions between the geo-, eco-, climate and socio-economic system of the southern Baltic Sea region during the past 9,000 years have been investigated in an interdisciplinary manner (HARFF et al. 2005). In this context the coastal evolution of various barrier spits along the northeast German Baltic Sea coast has to be elaborated depending on the interplay of a glacially shaped relief and the postglacial relative sea-level (rsl) development. Both inherited relief and rsl determine the accumulation space available to build up accumulative coastal landforms. The relation between the accumulation space and the sediment supply provided by cliff and nearshore erosion and longshore sediment transport ascertain the time needed to fill the accumulation space and to generate subaerial landforms. It is the main target of the project to describe the initiation and development of these landforms in relation to sea-level variations, to determine their evolutionary stage and stability and to deduce information about their future behaviour. Here, we present results of onand offshore investigations performed in a typical section of NE coastal Germany to determine the character of the sedimentary deposits, their geological layering and to derive a standard profile. The sediment distribution data is used to calculate roughly the sediment volume of the barrier and to estimate the retreat of adjacent cliff sections. From the spatial distribution of the depositional facies, their relations to the local rsl curve and from the courses of different generations of beach ridges on the peninsula's surface a simple reconstruction of the barrier development is derived. Finally, conclusions about its stability and future development will be drawn.

\section{Study area}

Rügen is the largest German island at the southern Baltic Sea coast. Its coastal relief is characterized by bluff sections composed of Cretaceous chalk and/or Pleistocene outwash and till, interspersed with low barriers, spits and accreting forelands composed of Holocene sand and, to a minor extent, gravel. The barriers and spits provide shelter to some lagoons (locally called 'bodden'). The Holocene coastal segments owe their existence to sediment supplied alongshore from eroding sandy or loamy bluffs along the Pleistocene headlands. The cliff sections where the barrier necks are connected to the headlands act as hinge points and the proximal barriers display a similar retreat as the neighbouring cliffs. The dynamics of the more distal parts of the barriers depend more on wave climate, sediment supply and the depth of the receiving basin. 


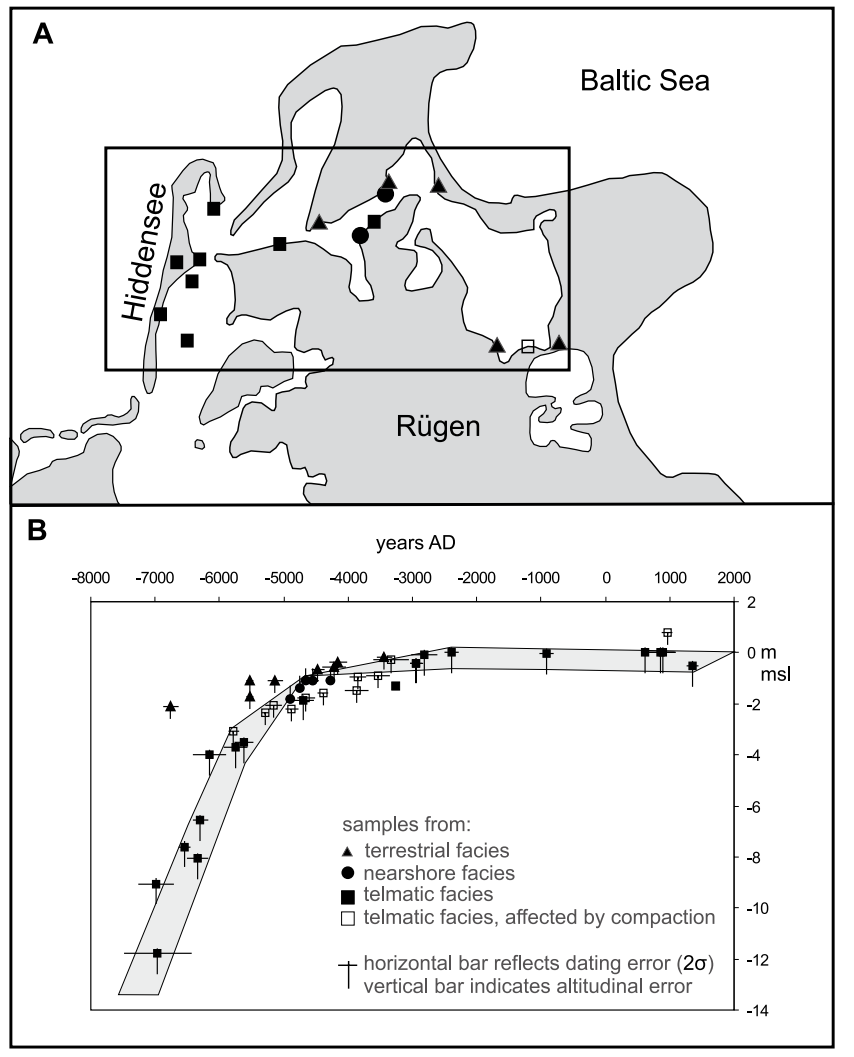

Fig. 2: Sampling sites (A) and relative sea-level curve of $N$-Rügen /Hiddensee (B). Triangles point to data from terrestrial deposits, circles to archaeological finds from marine nearshore deposits and black squares represent data from telmatic environments. White squares indicate data which are influenced by sediment compaction. Horizontal bars represent twofold standard deviation $(2 \sigma)$, vertical bars indicate estimated altitude error of sea level position. The error envelope indicates the interval where the sea level was most probably located.

Abb. 2: Probenahmepunkte (A) und relative Meeresspiegelkurve für das Gebiet N-Rügen /Hiddensee (B). Dreiecke entsprechen Daten aus terrestrischen Ablagerungen, Kreise markieren archäologische Funde aus marinen Seichtwasserablagerungen und schwarze Quadrate repräsentieren Daten aus telmatischem Milieu. Weiße Quadrate markieren Daten, die durch Sedimentkompaktion beeinflusst sind. Die horizontalen Balken zeigen die

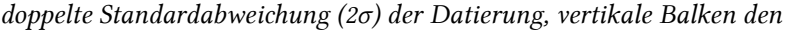
geschätzten Höhenfehler der Meeresspiegelposition an. Die Fehlerhüllkurve gibt den Bereich an, in dem der Meeresspiegel mit größter Wahrscheinlichkeit gelegen hat.

The Bug peninsula builds the north western part of Rügen island (Fig. 1). It is a $9 \mathrm{~km}$ long Holocene barrier spit with an area of $6.5 \mathrm{~km}^{2}$ and a $24 \mathrm{~km}$ long coastline. The width varies from a minimum of only $65 \mathrm{~m}$ at the neck in the north (Buger Hals) to a maximum of $1.5 \mathrm{~km}$ in the south-western part. The relief is generally flat with mean heights between $+0.8 \mathrm{~m}$ and $+1.5 \mathrm{~m}$ mean sea level $(\mathrm{msl})$ and a maximum of $+3.7 \mathrm{~m} \mathrm{msl}$ at dunes exposed to the open sea.

Since the first third of the twentieth century the study area was used as a military base. Due to the adherent access restrictions it was poorly investigated. Since 1991 the area is part of the National Park "Vorpommersche Boddenlandschaft" and again access is strongly limited. Therefore, previous surveys were done to only minor extent by mapping surface structures (SchüTZE 1931) and by drilling one borehole in the northern part from which a detailed sediment description is available (KLIEWE \& JANKE 1991). Some buildingground surveys around the former military harbour were performed related to renaturation tasks from which rather vague information exist. Central, southern and offshore areas remained so far unexplored.

According to ScHüTZE (1931) the land surface structures can be divided into two categories: the flat areas consist of levelled previous beach ridge and dune systems, the remaining areas are characterized by wide spaced curvilinear beach ridges. The course of the $-2 \mathrm{~m}$ isobath shows that the nearshore area surrounding the peninsula is wide and particularly shallow along the eastern and southern lagoonal side (Wieker Bodden, Rassower Strom) and narrow and steep with inclinations of 6 to 8 degrees along the coast exposed to the Libben bight in the west (Fig. 1). In the north the peninsula is connected via the Buger Hals to Wittow, the most northern Pleistocene morainic upland of Rügen with cliffs up to $+27 \mathrm{~m}$ msl high. The western shore of the Libben bight is build by the Hiddensee island with its distinctive, up to $72 \mathrm{~m}$ high cliffs and two adjoining barrier spits (Alt- and NeuBessin). Today, the Hiddensee sediment transport system is not or not significantly connected to the sediment transport system of the Bug peninsula due to a dividing inlet in between (Fig. 1).

The water-level history in the Baltic basin is characterized by an alternation of freshwater and brackish/marine phases with water tables of different heights varying between -15 to -40 m msl (BJÖRK 1995; LAMPE 2005). Due to the altitudinal position of the Pleistocene subground of the Bug peninsula none of them has influenced the investigation area. After the postglacial ocean water table had risen to the land surface altitude in the Danish Belts the Baltic basin became permanently connected to the North Sea at around 7,200 BC (BENNIKE et al. 2004, RössLER 2006). The subsequent sea level rise is called the Littorina transgression (named after the marine gastropod Littorina littorea) which completely reshaped the area of the today southern Baltic coast. During the early transgression phase the rise occurred rapidly with an ascent of about $10 \mathrm{~mm} / \mathrm{yr}$ but slowed later on. Earlier investigations have shown that on Rügen the sea level reached a position of $-5 \mathrm{~m} \mathrm{msl}$ at c. $6,000 \mathrm{BC}$ and a level between -1 to $-0.5 \mathrm{~m} \mathrm{msl}$ at c. 4,500 BC (KLIEWE \& JANKE 1982). For the subsequent some thousand years the sea level showed no significant variations but started to rise again at about 1000 AD (Late Subatlantic Transgression, LAMPE \& JANKE 2004; LAMPE 2005).

In this study no absolute age data could be gathered. The chronostratigraphical framework, therefore, bases on results from adjacent areas, such as the barriers Hiddensee, Schmale Heide and Schaabe, the north Rügen lagoons (Fig. 1) and their coastal sediment wedge as well as the numerous well dated archaeological on- and offshore sites known from this region (MÖBUS 2000; BARTHEL 2002; LÜBKE 2005; LAMPE $2005 \mathrm{a}, \mathrm{b})$. From these studies a set of 42 reliable AMS ${ }^{14} \mathrm{C}$ data was derived and arranged to a rsl curve (Fig. 2) which specify the data previously published by KLIEWE \& JANKE (1982). The curve represents the sea-level development in a spatially limited area of only about $30 \mathrm{~km}$ in diameter. Thus, the error due to differential earth crustal motions is avoided which is inherently included when using a larger sampling area in which isostatic movements occur (KIDEN et al. 2002).

According to a long-term gauge record the recent sealevel rise rate in the north Rügen area amounts to c. $0.6 \mathrm{~mm} /$ yr (Dietrich o Liebsch 2000). This is the lowest value ob- 
served along the northeast German Baltic coast and points to the influence of ongoing glacio-isostatic movements. Although not yet exactly quantifiable the recent regional eustatic rise is estimated to about $1 \mathrm{~mm} / \mathrm{yr}$ which in turn leads to a glacio-isostatic uplift of c. $0.4 \mathrm{~mm} / \mathrm{yr}$. The zero-uplift isobase runs around $75 \mathrm{~km}$ further south. Tidal variations are below $0.1 \mathrm{~m}$ and negligible for the southern Baltic Sea (Ministerium FÜr BAU, LANDESENTWICKLUNG UND UMWELT MECKLEnBURG-Vorpommern 1994). Therefore, coastal dynamic processes in this area are generally steered by inherited relief, sea-level variation and sediment supply.

\section{Methods}

To collect geophysical and sediment data from terrestrial as well from offshore sites of the peninsula, three field campaigns were performed in 2002, 2005 and 2008. In cooperation with the Leibniz Institute for Applied Geophysics, Hannover, ground-penetrating radar (GPR) surveys were conducted at the central and southern peninsula (Fig.1; dashdotted lines). A SIR-10 respectively SIR-20 set from GSSI with a $100 \mathrm{MHz}$ antenna were used to determine the bedding structures within the upper sediment layers. Reflectors are recorded for two-way-travel times of up to $200 \mathrm{~ns}$ and were related to depth using a constant $\mathrm{v}=0.07 \mathrm{~m} / \mathrm{ns}$ derived from repeated common midpoint measurements. These parameters allowed a subsurface imaging of the upper $8 \mathrm{~m}$ below land surface. To optimise the resolution in various depths additional GPR profiles were recorded along two previous tracks. One connects the cores Bug 1-10 and a second runs from the coast into south-western direction along the cores Bug 11-15. At these sites different antenna frequencies were tested $(200,100$ and $50 \mathrm{MHz})$ using a RAMAC-GPR set. As a result the $50 \mathrm{MHz}$ antenna was used to detect the base of the Holocene sediments which was expected in depths at about $10 \mathrm{~m}$ below surface.

According to the GPR measurements 16 core sites were identified at both track positions where reflectors were clearly visible or were minor / no resolution of the subsoil did not allow the identification of any subsoil layering. To derive geological cross sections across the barrier the sites were arranged to one profile crossing the peninsula from northwest to south-east perpendicular to the coastline (Fig.1, cores Bug 1-10) and to a second profile running lengthwise (cores Bug 10-16). The objective was to detect both the bases of the Holocene and the marine sediments, and to identify the composition of the marine deposits. For the drilling process a hydraulic powered drill and extraction tool was applied. Depending on the penetration resistance of the sediments three different diameters of half-open testing probes $(80,50$, $36 \mathrm{~mm}$ ) were used. A maximum depth of $-13.85 \mathrm{~m}$ msl was reached at core Bug 15.

In 2008 a third campaign was performed to collect offshore data on board the research vessel "Prof. Albrecht

Tab.1: Facies types differentiation of the Bug peninsula and features of classification.

Tab.1: Faziesdifferenzierung der Halbinsel Bug und Merkmale der Klassifikation.

\begin{tabular}{|c|c|c|c|c|c|}
\hline Facies type & $\begin{array}{l}\text { Grain size } \\
\text { Md - median } \\
\text { So - sorting }\end{array}$ & $\begin{array}{l}\text { Organic } \\
\text { content }\end{array}$ & $\begin{array}{l}\text { Carbonate } \\
\text { content }\end{array}$ & $\begin{array}{l}\text { Fauna } \\
\text { species / abundance / type of shell } \\
\text { destruction / salinity range } \\
\text { (abundance: 1-very low, 2-low, 3-modest, 4-high, } \\
\text { 5-very high) }\end{array}$ & Environment \\
\hline glacial & $\begin{array}{l}\text { clayey-sandy matrix, } \\
\text { gravel, stones, chalk } \\
\text { Md: } 0.32 \mathrm{~mm} \\
\text { So: } 1.27\end{array}$ & none & very high & no sample analysed & glacial \\
\hline fluviolimnic & $\begin{array}{l}\text { fine sand } \\
\text { Md: } 0.19 \mathrm{~mm} \\
\text { So: } 1.32\end{array}$ & none & $\begin{array}{l}\text { medium to } \\
\text { high }\end{array}$ & Bryozoa / 1 / small fragments / ? & $\begin{array}{l}\text { freshwater / } \\
\text { (aeolian?) }\end{array}$ \\
\hline shoreface & $\begin{array}{l}\text { fine to medium sand } \\
\text { Md: } 0.09 \mathrm{~mm} \\
\text { So: } 1.59\end{array}$ & $\begin{array}{l}\text { none, some- } \\
\text { times thin } \\
\text { organic layers } \\
\text { of } \sim 10 \%\end{array}$ & none & $\begin{array}{l}\text { Mytilus edulis / } 1 \text { / fragments / 15-40 PSU } \\
\text { Cerastoderma edule / } 1 \text { / fragments / >5 PSU } \\
\text { Littorina littorea / } 1 \text { / unbroken / >9 PSU }\end{array}$ & $\begin{array}{l}\text { brackish - } \\
\text { marine }\end{array}$ \\
\hline slack water & $\begin{array}{l}\text { silt, upper parts fine } \\
\text { sandy } \\
\text { Md: } 0.05 \mathrm{~mm} \\
\text { So: } 1.89\end{array}$ & $7-15 \%$ & none & $\begin{array}{l}\text { Mytilus edulis / } 4 \text { / fragments / 15-40 PSU } \\
\text { Cerastoderma sp. / } 3 \text { / fragments - bivalve / >5 PSU } \\
\text { Hydrobia ulvae / } 2 \text { / fragments - unbroken / >4 PSU } \\
\text { Cyprideis torosa / } 2 \text { / single shells - bivalve / 8-9 PSU }\end{array}$ & $\begin{array}{l}\text { brackish - } \\
\text { marine }\end{array}$ \\
\hline nearshore & $\begin{array}{l}\text { fine to medium sand } \\
\text { Md: } 0.18 \mathrm{~mm} \\
\text { So: } 1.27\end{array}$ & $\begin{array}{l}\text { none, some- } \\
\text { times thin } \\
\text { organic layers } \\
\text { of } \sim 10 \%\end{array}$ & none & $\begin{array}{l}\text { Mytilus edulis / } 4 \text { / fragments / 15-40 PSU } \\
\text { Cerastoderma sp. / } 3 \text { / fragments \& single shells / >5 PSU } \\
\text { Hydrobia ulvae / } 2 \text { / / >4 PSU }\end{array}$ & $\begin{array}{l}\text { brackish - } \\
\text { marine }\end{array}$ \\
\hline beach & $\begin{array}{l}\text { medium to coarse sand, } \\
\text { gravel, small stones } \\
\text { Md: } 0.45 \mathrm{~mm} \\
\text { So: } 1.39\end{array}$ & $\begin{array}{l}\text { none, some- } \\
\text { times botanical } \\
\text { macro remains } \\
\text { of the drift line }\end{array}$ & none & $\begin{array}{l}\text { Mytilus edulis / } 3 \text { / fragments / 15-40 PSU } \\
\text { Cerastoderma sp. / } 2 \text { / fragments / > } 5 \text { PSU } \\
\text { Hydrobia ulvae / } 1 \text { / fragments / >4 PSU }\end{array}$ & $\begin{array}{l}\text { brackish - } \\
\text { marine/ } \\
\text { (aeolian?) }\end{array}$ \\
\hline
\end{tabular}




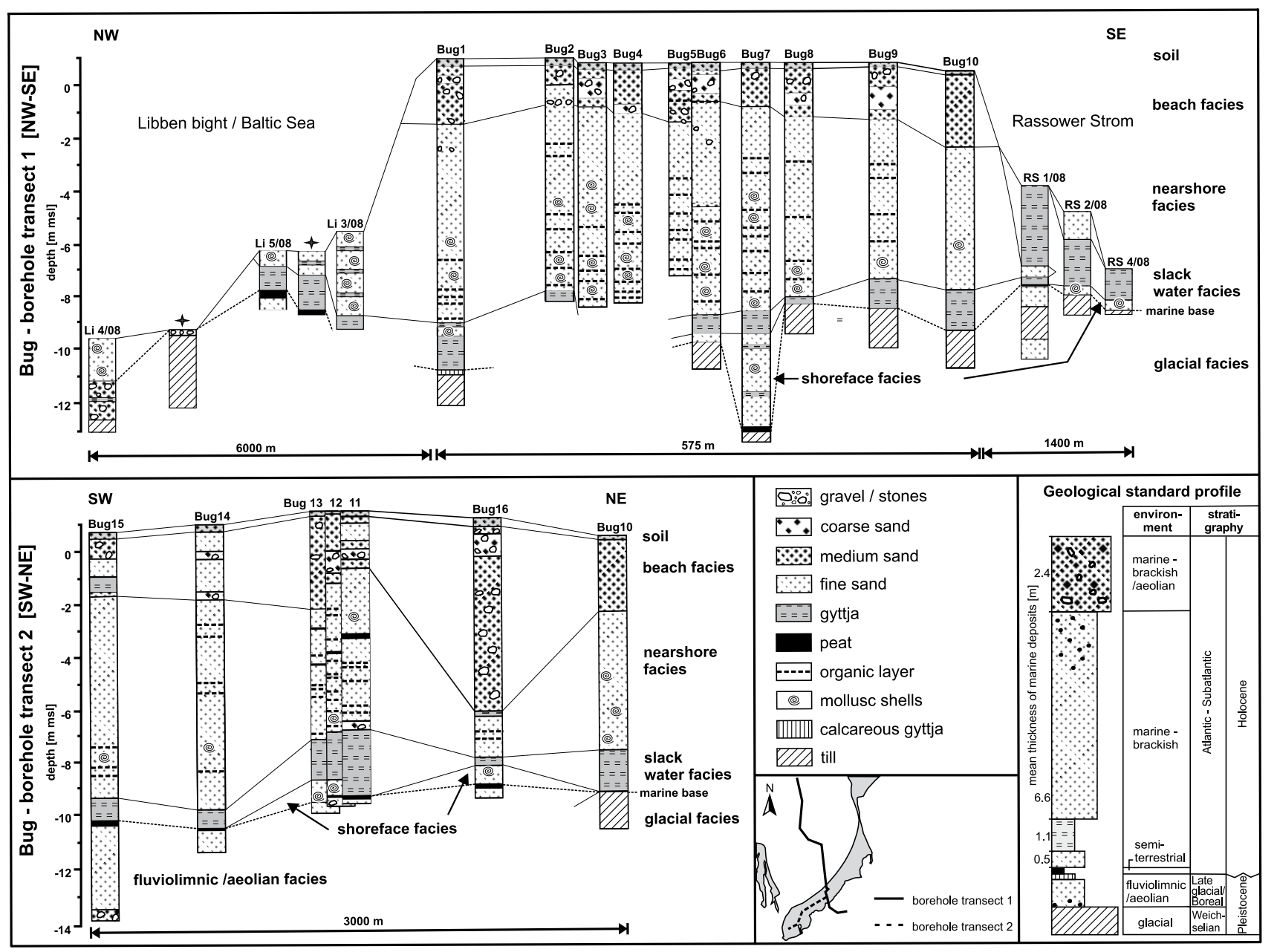

Fig. 3: Core profiles and facies distribution along two transects (for location see Fig. 1) and geological standard profile of the sediment sequence in the study area.

Abb. 3: Bohrkernprofile und Faziesverteilung entlang zweier Transekte (zur Lage s. Abb. 1) sowie geologisches Normalprofil der Schichtenabfolge des Bugs.

Penck". Six sediment-echosounding (SES) transects were recorded in the Libben bight with an Innomar SES-96 set by using a frequency of $6 \mathrm{kHz}$ and $1500 \mathrm{~m} / \mathrm{s}$ sound velocity (Fig. 1; dotted lines). This setting delivered useful information about reflectors up to $8 \mathrm{~m}$ below sediment surface. Signals from larger depths were mainly multiples. Five vibrocores were taken of $3.80 \mathrm{~m}$ maximal length ( $\mathrm{Li} 3 / 08)$ to allow interpretation of detected SES reflectors. From board the research barge "Bornhöft" additional 4 sediment cores were taken in the shallow lagoon Rassower Strom to expand the shorenormal barrier cross section to south-eastern direction. Thereby, a maximum penetration of $6.60 \mathrm{~m}$ below sediment surface was reached at core RS 1/08.

All cores were classified into lithological units characterized by grain size, calcium carbonate and organic content as well as the occurrence and species assemblage of macrofossils. In five exemplary cores (Bug 1, 9, 11, 15, 16) the units identified were sampled for lab analysis and closer characterization. The granulometric composition of 48 samples was measured by dry sieving, 13 fine clastic samples were analysed using an optical laser sizer device (Fritsch Analysette 22). To characterize the grain size distribution the TRASK-parameters median and sorting were calculated (FüсHTBAUER $\mho$ MüLLER 1970). Organic content was determined as loss on ignition at $550{ }^{\circ} \mathrm{C}$, carbonate content was determined qualitatively according to AG BoDEN (1994). From 16 samples (11 samples from Bug 13 and additional samples from the basal marine layers from Bug $11 ; 15 ; 16)$ the palaeo-environments in which the different sediments were deposited were analysed by determination of faunal remnants, mainly from molluscs.

\section{Results}

\section{Lithofacial units}

The analysis of the geophysical and lithological data along with previously achieved field data from the northern Bug lead to the identification of six different sedimentary facies units. As distinctive features were used: i) the grain size distribution and deduced parameters such as median and sorting as surrogates for the transport and deposition dynamics, ii) the organic content of the sediment which indicates deposition under temperate and faintly dynamic conditions, iii) a low or missing calcium-carbonate content as an indicator that the primary Pleistocene material underwent weathering during relocation and redeposition, iv) species assemblage, mainly from molluscs, which points to a certain salinity of the palaeo-environment (РеACOCK 1993), while the degree of shell destruction reflects the water dynamics. An overview about the lithological units, the related facies types and the classification features is given in table 1 . The geological 


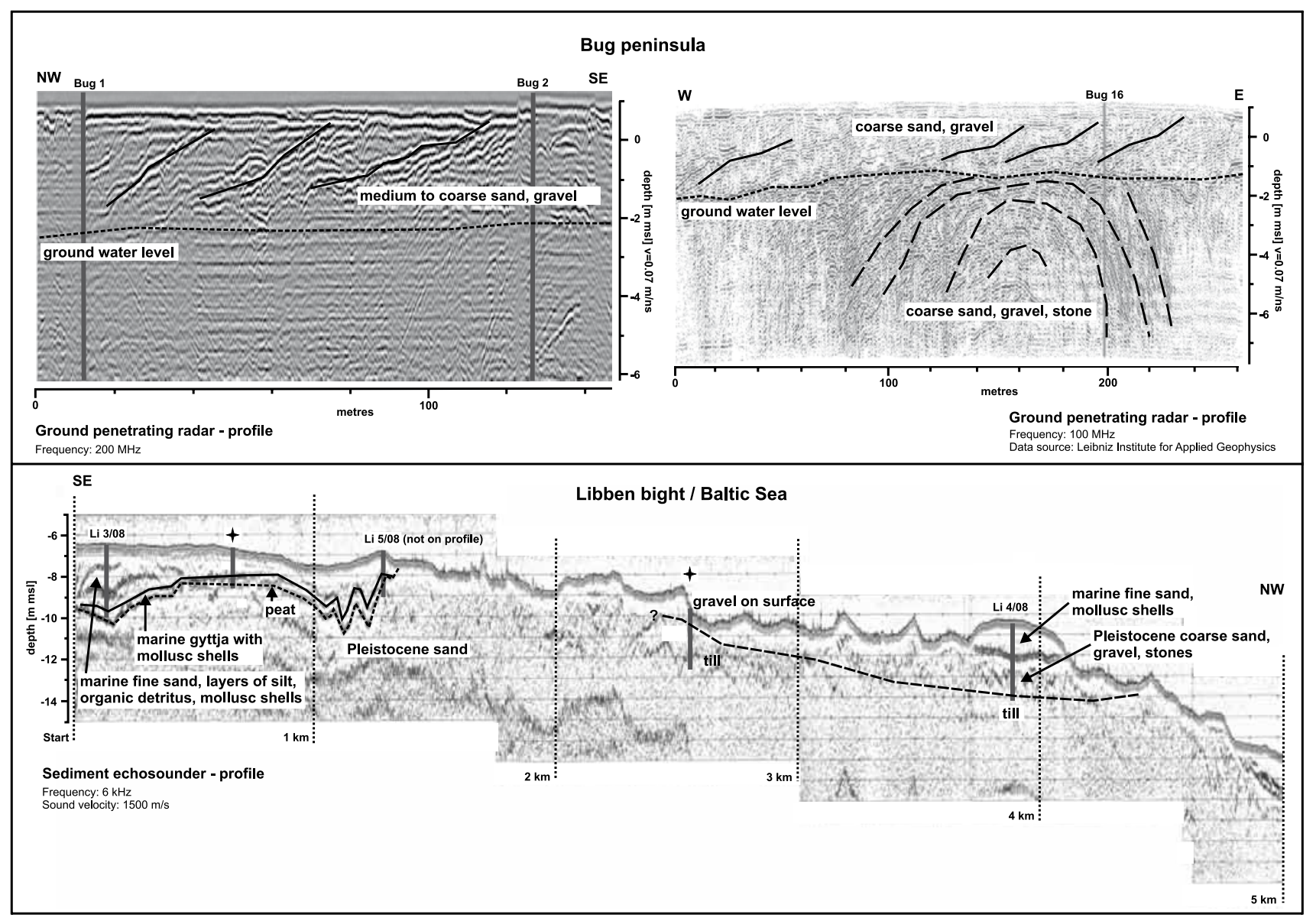

Fig. 4: Two ground penetrating radar profiles from the central and southern peninsula (for location see Fig. 1) showing bedding structures of progradational beach ridges (upper section). Sediment-echosounding profile from the Libben bight (for location see Fig. 1) showing distribution of different sediments in the subground (lower section).

Abb. 4: Zwei Bodenradar-Profile aus dem zentralen bzw. südlichen Bereich der Halbinsel (zur Lage s. Abb. 1), die Lagerungsstrukturen progradierender Strandwälle zeigen (oben). Sedimentecholot-Profil aus der Libben-Bucht (zur Lage s. Abb. 1), welches die Verteilung unterschiedlicher Sedimente am Meeresboden verdeutlicht (unten).

standard profile of the Bug (Fig. 3) was deduced considering the mean thickness and the vertical succession of the observed units. In the following paragraphs the observed facies units are described more detailed.

At nearly all borehole positions the sediment sequence started (except in Li 3/08; Bug 2-5) with a diamicton, a calcareous clayey to sandy matrix with admixtures of coarser grains like gravel and stones. Although it may be of slightly different origin we subsume all of them under the glacial facies type till. The upper boundary of the till is located in depths between -9 to $-14 \mathrm{~m}$ msl in the central part of the peninsula (Fig. 3; borehole transect 1), whereas in the southern part the till surface was not reached and must be located lower than $-14 \mathrm{~m}$ msl (Fig. 3; borehole transect 2). In the Libben bight the boundary was found in the same depth range as in the central Bug area. Farther offshore the covering sediment wedges and till forms the sea bottom (Fig. 4; SES-profile).

Above the till calcareous fine sand follows containing Bryozoa relicts, which originate from Cretaceous sediments. This sandy unit was detected below $-9.50 \mathrm{~m} \mathrm{msl}$ and is spatially limited to the south western part of the peninsula (Fig. 3; borehole transect 2, cores Bug 11-16) and to some nearshore areas of the Libben bight (Fig. 4; SES-profile). The sand is of (glaci-)fluvial or -lacustrine origin as many other sandy sediment bodies of the same character and altitudinal position known from the vicinity. In places lake marl or calcareous gyttja were found in flat depressions on the sand surface and point to deposition in shallow lakes under warmer climate conditions. All these freshwater sediments were combined in the fluviolimnic facies unit.

The subsequent transition from freshwater to marine environmental conditions was often marked by the occurrence of semi-terrestrial peat (semi-terrestrial facies), which developed close to the water level in sheltered zones. Layers of 3 to $15 \mathrm{~cm}$ thickness were found in various depths between -8 and $-13 \mathrm{~m}$ msl and on top of diverse deposits (till, fine sand, calcareous gyttja).

The sediment in the hanging wall was always clearly deposited in a marine environment. Non calcareous fine sand with minor contents of well preserved marine molluscs (Cerastoderma sp., Mytilus edulis, Littorina littorea) are related to the shoreface facies. Found in small depressions between -8.20 and $-12.80 \mathrm{~m} \mathrm{msl}$ it occurs only sub-dominant in the study area (cores Bug 6, 7, 12, 13, 16 and RS 1, 2, 4).

It is overlain by a consolidated dark grey to black coloured gyttja containing 7 to 15 weight per cent of organic matter. At the base reworked peat and botanical macro remains like wood were sometimes visible. In the lower part a massive occurrence of shells of marine molluscs (Cerastoderma sp., 
Mytilus edulis, Hydrobia ulvae) and ostracods (Cyprideis torosa) is symptomatic. Predominantly, the shells are arranged in tiers which consist of shell fragments but bivalve shells with intact ligaments are often found in between. Both grain size and shell distribution point to deposition under calm water conditions near the storm wave base, where dislocation and redeposition occur occasionally (slack water facies). The sediment type is widespread in the subground of the peninsula and fills the back-sided lagoon, ranging in depths between $-3.70 \mathrm{~m}$ and $-10.50 \mathrm{~m} \mathrm{msl}$. To the upper boundary the content of organic matter as well as the amount of mollusc shells decreases and the mean grain sizes gets a bit coarser due to a larger fine sand fraction.

The nearshore facies is characterized by non calcareous fine to medium sands with numerous 1 to $5 \mathrm{~cm}$ thick interbedded layers of organic detritus and/or mollusc shells. Fragments of Cerastoderma sp. and Mytilus edulis are readily identifiable and indicate a marine-brackish depositional environment. Fine sand is the dominant grain size pointing to shallow water conditions where sediment is transported mainly in suspension. Within the unit a slight coarsening upward and a decreasing amount of organic layers and mollusc shells indicate growing water dynamics and redeposition intensity. Owing a calculated mean thickness of $6.6 \mathrm{~m}$ this sediment unit builds the main part of the barrier comprising approximately two third of the Holocene sediment volume.

The uppermost sediment unit shows a mixed and less well sorted grain size spectrum. It consists of medium to coarse sand containing gravel and some small stones, too. The lack of fine clastic material and the occurrence of heavy fragmented mollusc shells indicate rough water and sediment dynamics characteristic for beach facies. The spatial occurrence is different across the peninsula but dominant where beach ridge formation takes place. The depth interval in which the sediment unit appears reaches from the land surface down to $-2 \mathrm{~m}$ msl.

A schematic overview about the distribution of the lithofacial units is depicted in two geological cross sections (Fig. 3). The glacial, fluviolimnic and semi-terrestrial deposits are separated from the brackish-marine deposits by a more or less erosive surface, the marine base. It is built by the lower boundary of the shoreface or the slack water facies.

The vertical succession and the mean thickness of the marine layers are shown in the geological standard profile. Hence follows that the thickness of the Holocene sediment sequence of the Bug pensinsula amounts to around $10 \mathrm{~m}$. A similar thickness was found for other barriers along the southwestern Baltic coast (HofFMANN 2004, HofFmANN et al. 2005).

\section{Internal bedding structures}

GPR/SES investigations along on- and offshore transects facilitate the correlation of the lithofacial units identified from the sediment cores and the determination of their spatial distribution. Internal bedding structures might be attributed to specific depositional processes allowing a more precise reconstruction of the palaeogeographic evolution.

The SES profile running perpendicular to the coastline of the Bug (Fig.1 and Fig. 4; lower section) shows the transi- tion from the Arkona Basin in the NW to the inner Libben bight. From the edge of the Arkona Basin at profile $\mathrm{km} 4.5$ to $\mathrm{km} 1.4$ the sea bottom is rough and covered with numerous boulders, which are evident from the many spikes on the sediment surface. The sediment cores taken show that till appears near to the surface and is covered by lag sediment. A flat, $400 \mathrm{~m}$ wide sand bar was observed at the border to the Arkona basin (core Li 4/08) deposited on the till. The subaquatic boundary of the barrier is located close to core Li 5/08 at profile $\mathrm{km} 1.3$ and around $3 \mathrm{~km}$ offshore the Bug peninsula. Here, under marine sand the most seaward occurrence of the slack water facies was observed which can be traced into the subground of the today barrier.

GPR records from the barrier show bedding structures in the upper subsurface down to $-2 \mathrm{~m}$ msl (Fig. 4; left upper section). Unfortunately, the occurrence of salty groundwater prevents a reception of information from greater depths. The bedding structures are characterised by a constant inclination towards the sea and are clearly related to accretionary beach ridges evident at the surface. The structures were also found in some flat areas where no beach ridges occur on the surface. This is most probably caused by subsequent erosion and levelling of the former relief due to overwash processes during storm floods.

Information from bedding structures at greater depths is limited to some central parts of the peninsula having less salty groundwater in the subsoil (Fig. 4, right upper section). Here, a massive coarse grained marine sediment body was identified, proven by core Bug 16 . The GPR record shows strata down to $-6 \mathrm{~m}$ msl with complementary inclinations. In a depth of about -1.5 to $-2 \mathrm{~m}$ msl the sediment body is discordantly overlain by accretionary beach ridges as described above.

\section{Interpretation}

From the spatial distribution of the lithofacial units and the information about sediment bedding structures a model of the coastal development in the study area is deduced. Thereby, the rsl curve of N-Rügen/Hiddensee (Fig. 2) is used for information about sea-level rise rates, changes in accommodation space and the relation of the sediment deposition to time scale. Fig. 5, left side, illustrates in seven characteristic stages the vertical sediment accumulation on a $10 \mathrm{~km}$ long geological cross section, running lengthwise the peninsula from the south-western barrier tip to Dranske village in the north-east (cf. Fig. 1). The stages are related to periods known from previous investigations as characteristic for the regional landscape evolution (LEMKE 1998, LEMKE et al. 2001; KAISER 2001). On the right side of Fig. 5 the coastline evolution is depicted in four plan-view sketches A-D within which the recent coastline is drawn by a dotted line.

The first sketch (Fig. 5, left side) displays the till surface at the end of the last pleniglacial around 12,000 BC. The stratigraphic classification within the Weichselian glacial period cannot be specified, but a relation to the North Rügen icemarginal zone is obvious (KLIEwE 1975). The till surface at the Wittow headland near Dranske is found at about $+5 \mathrm{~m}$ $\mathrm{msl}$. From there it drops gradually around $20 \mathrm{~m}$ to southwestern direction. During the Late glacial period this depression was partly filled with (glaci-)fluviolimnic sand accumu- 


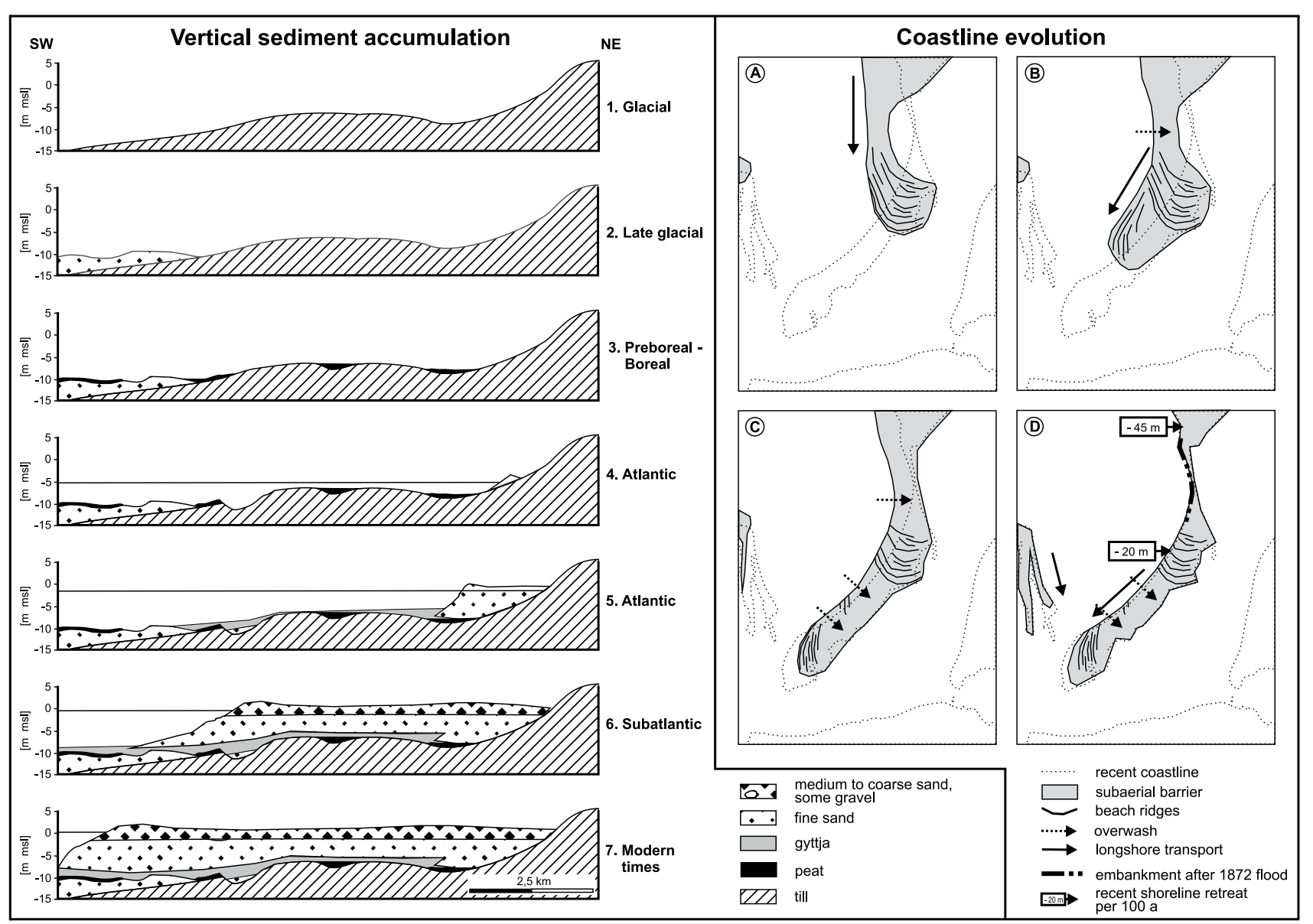

Fig. 5: Coastal evolution of the Bug peninsula, illustrated in seven evolutionary stages showing the vertical sediment accumulation (left part), and by four plan view sketches showing the shoreline development (right part).

Abb. 5: Küstenentwicklung der Halbinsel Bug. In sieben Entwicklungsstadien ist die vertikale Sedimentakkumulation wiedergegeben (linker Teil), vier Kartenskizzen verdeutlichen die Uferlinienentwicklung (rechter Teil).

lated in channels and basins where meltwater drained in western directions (Möвus 2000) towards the Arkona Basin (stage 2).

After final ice melting the area felt dry and terrestrial evolution started due to the water-level fall in the Baltic basin to $-40 \mathrm{~m}$ during the Younger Dryas/Early Preboreal. Interstadial deposits (e.g. Allerød) are well known from the wider vicinity but were not found in the study area. Likewise, from the Younger Dryas significant wind-driven sediment redeposition is known from the region. Although not proven in the study area it has to be considered that the fluviolimnic sand was relocated to some extent. After the onset of the Holocene and a rise of the ground-water table mires or shallow lakes came into being on the gently undulating land surface. In the waters lake marl or calcareous gyttja were deposited (for instance in core Bug 1 at $-10.50 \mathrm{~m} \mathrm{msl}$ ) but most waters turned soon into mires and desiccated (stage 3 ).

In a fourth stage the groundwater table started to rise again caused by the Littorina transgression. Basal peat developed in a narrow belt in front of the transgressing shoreline. The local rsl curve (Fig. 2) shows that the sea-level reached the study area c. 7,000 BC, which was subsequently rapidly inundated. The shoreface facies unit which covers the basal peat deposits is interpreted as a trailing edge sand sheet (Roy et al. 1994), which was left behind a transgressing beach ridge. It filled small depressions and channels eroded during the inundation thereby levelling the surface. Perhaps, the flat sand body found on the SES transsect at $\mathrm{km} 3.8$ to 4.1 between -10 to $-12 \mathrm{~m}$ msl (Fig. 4 ) is a relic barrier overstepped by the rapid rising sea level. Today it seems to be shaped and nourished by contour bounded currents and sand transport between the headlands of Hiddensee and Wittow.

The fifth sketch shows the status at the end of the main transgression phase about 4,500 BC. In the period between the fourth and the fifth stage the sea level rose rapidly and generated fast increasing subaquatic accumulation space, where fine clastic material (slack water facies) was deposited near at or below the wave base. Wave impact from NW to $\mathrm{NE}$ and related cliff abrasion provided material for longshore transport. However, accumulative coastal landforms grew still to only minor extent because the accommodation space increased faster than it was filled. Since the time the sealevel rise decreased accumulation became more dominant and the main barrier was built up in only some two thousand years. In this time span the lagoon became separated from the open sea. The coastline was located more westerly and the barrier spit grew into southern direction. Beach ridges were north-south oriented with their ends turned to east (Fig. 5; plan view A).

The final development is depicted in the last two sketches, where sediments of nearshore and beach facies shaped the peninsula. While erosion and shoreline transgression continued in the northern part sediment aggradation and spit elongation dominated at the tip of the peninsula. With increasing 
length the peninsula's tip became more and more sheltered by Hiddensee island. While ongoing abrasion took place in the less sheltered northern section decreasing wave impact and altered wave refraction changed the elongation at the tip to south-westerly direction (Fig. 5; plan view B). Probably, the latter process proceeded discontinuously. It must be assumed that the accumulation of the gravelly beach ridge found in borehole Bug 16 (Fig. 3 and Fig. 4) coincided with a retardation in the elongation process, caused by the large volume of coarse material to be deposited. As the remaining barrier is composed of sandy sediments a coarse glacifluvial deposit of rather limited extent is hypothesized as the source of the gravel. Due to complete abrasion and redeposition and/or incomplete survey data the primary location of the source is unknown but is estimated NW of the today beach ridge. Similar deposits are known from the wider vicinity of the study area (JACOB 1987, SCHWARZER et al. 2000) and corroborate this interpretation.

Since the sea level started to rise faster again at about $1000 \mathrm{AD}$ the barrier was particularly shifted landwards by erosion and overwash. Therefore, only the very ends of the former beach ridges remained in the north and central barrier sections (Fig. 5; plan view C) now interspersed with overwash plains. After the destructive storm flood in 1872, during which the narrow neck of the barrier (Buger Hals) was inundated and scoured, an embankment was built for protection (Fig. 5; plan view D). Since then erosion decreased but artificial nourishment is still required to prevent breakthrough. More recently, the southern barrier section was strongly affected, too. For a few decades dredging operations in the now abandoned waterway between Hiddensee and Bug caused decreasing spit elongation while the dredged material was spoiled at the lagoon-sided tip of the peninsula (Fig. 5; plan view D). Future development unaffected by human intervention would probably lead to a permanent closure of the inlet between the Neu-Bessin spit and the Bug and a detachment of the peninsula's neck from the Wittow headland. While the remaining peninsula would shrink in the north the material eroded would cause beach ridge progradation in the south.

To get an impression how much material was accumulated in the barrier and how extensive the abrasion at the neighbouring cliffs must have been, the volume of the marine sediments was calculated. Due to missing information about the relief and the sediment distribution at both seeward and lagoonward shorefaces fringing the barrier the calculation was restricted to the volume enclosed by the marine base below the peninsula's land area and whose surface (HOFFMANN \& LAMPE 2007). This volume amounts to 66.4 million cubic metres (NAUMANN 2006). As the only feeding section the adjacent $8 \mathrm{~km}$ long and on average $8 \mathrm{~m}$ height cliff at Wittow is assumed which implies a cliff retreat of $1,040 \mathrm{~m}$. However, the factual abraded volume must have been much larger. Firstly, as the shoreface volume was ignored in the calculation and secondly, because the fine fraction of the abraded Pleistocene material, which amounts to c. $40 \%$, became not completely involved in the coastal sedimentary system. A portion was deposited in the slack water facies, but the remaining part accumulated as mud in deeper offshore basins. Hence, the real cliff retreat might amount to twice the calculated value. The recent retreat rates account to $45 \mathrm{~m} / 100 \mathrm{yr}$ at the Wittow cliff section and $20 \mathrm{~m} / 100 \mathrm{yr}$ at beaches along the sheltered inner Libben bight (MINISTERIUM FÜR BAU, LANDESENTWICKLUNG UND UMWELT MECKLENBURG-VORPOMMERN 1994). Considering that the oldest beach ridges still visible on the only $500 \mathrm{~m}$ wide barrier have an age of about 5,000 to 6,000 years (SCHÜTZE 1931, KLIEWE \& JANKE 1978) this means that the abrasion rates must have been significantly lower in the period after 4,500 BC. This finding is interpreted as a consequence of the some thousand years displaying no rsl rise (Fig. 2) and were related to decreasing shoreline erosion. Only the onset of the Young Subatlantic Transgression was associated again with higher shoreline dynamics. Although the anew rise which started at about $1000 \mathrm{AD}$ was interrupted during the Little Ice Age it continued since $1850 \mathrm{AD}$ as documented in gauge records (Dietrich \& LIEBSCH 2000).

The conclusion that over some thousand years the lateral translation was rather low when compared with recent displacement rates seems to be in conflict with the occurrence of marine gyttja (slack water facies) in boreholes Li 3/08 and Li 5/08 (Fig. 3 and 4) about $3 \mathrm{~km}$ offshore. One is tempted to conclude an initial barrier in the west from the boreholes which subsequently migrated to the recent position. However, the gyttja was found where the pre-transgressional relief displays a depression with an inclination of the surface towards the south and/or east (Fig. 4). Even the rising ground water would cause a lagoonary water in a position such as this. Although not proven by borings we speculate that this depression is part of a larger depression the centre of which is located in the area SW of the Bug spit. Here, the deepest position of the marine base is reached in boreholes Bug 14 and Bug 15 at about $-10 \mathrm{~m}$. From the southern tip of the Alt-Bessin (Fig. 1) a position of the marine base of $-12 \mathrm{~m}$ was reported by Hurtig (1954) and of -20m at central Hiddensee by BARTHEL (2002). The connecting channel between the depression and the rising sea was obviously not located in the Libben bight and must be assumed farther west in the Hiddensee area (Fig. 1). For this reason the occurrence of the marine gyttja $3 \mathrm{~km}$ offshore the today peninsula is not in contradiction to the evolutionary stages of the peninsula depicted in Fig. 5.

\section{Conclusions}

The investigated barrier represents a paraglacial, drift aligned coastal system (ForBes et al. 1995). It became established on a slightly undulating surface of glacigenic and glacifluvial origin with low inclination towards the Baltic Sea basin. The barrier evolution started with the arrival of the Littorina transgression about 7,000 years $\mathrm{BC}$ as a beach ridge migrated over the land surface and finally stranded at the Wittow headland. Its trailing edge sand sheet levelled the inundated and scoured surface. During the next some two thousand years the sea-level rise rate was still high and the accommodation space grew faster than it was filled by the sandy material provided by cliff erosion. The sea-level rise slowed down at $4,500 \mathrm{BC}$ and came virtually to a halt at 4,000 BC due to compensating glacio-isostatic uplift. Since then the accommodation space shrunk and fast spit elongation took place. Erosion at the headland hinge point and along the barrier shoreline drove the barrier landwards thereby migrat- 
ing over gyttja accumulated in the backbarrier lagoon. The propagation direction was changed after the extending barrier grew into the shelter of the windward located island Hiddensee. Ongoing erosion along the shoreline caused overwash processes which enhanced barrier transgression.

Today the barrier displays a volume of 66.4 million $\mathrm{m}^{3}$ according to a feeder cliff retreat of at least $1,040 \mathrm{~m}$, but probably about $2,000 \mathrm{~m}$, which is in the range of the general coastal retreat along the NE German and neighbouring Polish coast (Uścinowicz 2006). Although the barrier seems to be in maturity stage some features points to instability. Coastal protection measures at the barrier neck in the north prevent imminent breakthrough and detachment. Waterway dredging in the south inhibited further elongation and accretion with spits growing from Hiddensee. Without these measures the barrier would disintegrate and be reshaped by inlet generation and increasing erosion in the north and inlet closure and beach progradation in the south.

\section{Acknowledgment}

We thank J. Becker and C. Wünsche (Greifswald University) for their technical assistance during the field work and G. Nickel, M. Pötzsch (IOW, Warnemünde) and the crew of the research vessel "Prof. Albrecht Penck" for operating the SES and the vibrocorer. Further we are thankful to G. Büttner (Greifswald University) for technical support during the GPR campaigns and to R. Ziekur (LIAG, Hannover) for providing GPR data previously recorded in the study area. This investigation was conducted due to the financial support provided by the German Research Foundation (FO 488/1, subproject 1.1).

\section{References}

AG Boden (1994): Bodenkundliche Kartieranleitung (4. Auflage). - 392 S.; Hannover (BGR).

Barthel, A. (2002): Aufbau und Entwicklung der holozänen Sedimente der Insel Hiddensee und deren Modellierung mit geostatistischen Methoden. - Thesis, Geographisches Institut, Universität Greifswald, 109 S.

Bennike, O., Jensen, J. B., Lemke, W., Kuijpers, A. \& Lomholt, S. (2004) Late- and postglacial history of the Great Belt, Denmark. - Boreas 33: 18-33.

BJöRK, S. (1995): A review of the history of the Baltic Sea, 13.0-8.0 ka BP. Quaternary International, 27: 19-40.

Dietrich, R. \& Liebsch, G. (2000): Zur Variabilität des Meeresspiegels an der Küste von Mecklenburg-Vorpommern. - Journal of Coastal Research, 28/6: 615-623.

Forbes, D.L., Orford, J.D., Carter, R.W. G., ShaW, J. \& Jennings, S.C (1995): Morphodynamic evolution, self-organisation, and instability of coarse-clastic barriers on paraglacial coasts. - Marine Geology, 126: $63-85$.

Füchtbauer, H. \& Müller, G. (1970): Sediment-Petrologie. Teil II Sedimente und Sedimentgesteine. - 726 S.; Stuttgart (Schweizerbart'sche Verlagsbuchhandlung).

Harff, J., Lampe, R., Lemke, W., Lübke, H., Lüth, F., Meyer, M. \& TAuber, F. (2005): The Baltic Sea - A Model Ocean to Study Interrelations of Geosphere, Ecosphere, and Anthroposphere in the Coastal Zone. - Journal of Coastal Research, 21/3: 441-446.

Hoffmann, G. (2004): Postglacial to Holocene sedimentation history and palaeogeographical development of a barrier spit (Pudagla lowland, Usedom Island, SW Baltic coast). - Polish Geological Institute Special Papers, 11: 83-90.

HoffmAnn, G. \& LAMPE, R. (2007): Sediment budget calculation to estimate Holocene coastal changes on the southwest Baltic Sea (Germany). Marine Geology, 243: 143-156.

Hoffmann, G., Lampe, R. \& Barnasch, J. (2005): Postglacial evolution of barrier spits along the West Pomeranian coast (NE Germany). - Quaternary International, 133/134: 47-59.

Hurtig, T. (1954): Die mecklenburgische Boddenlandschaft und ihre entwicklungsgeschichtlichen Probleme. Ein Beitrag zur Küstengeschichte der Ostsee. - 148 S.; Berlin (Deutscher Verlag der Wissenschaften).

Jасов, H.-E. (1987): Die Fährinsel bei Hiddensee - Geomorphologie und Genese. - Petermanns Geographische Mitteilungen, 131: 85-92.

KAISER, K. (2001): Die spätpleistozäne bis frühholozäne Beckenentwicklung in Mecklenburg-Vorpommern. Untersuchungen zur Stratigraphie, Geomorphologie und Geoarchäologie. - Greifswalder Geographische Arbeiten, 24: $176 \mathrm{~S}$.

Kiden, P., Denys, L. \& Johnston, P. (2002): Late Quaternary sea-level changes and isostatic and tectonic land movements along the BelgianDutch North Sea coast: geological data and model results. - Journal of Quaternary Science, 17: 535-546.

KLIEwE, H. (1975): Spätglaziale Marginalzonen auf der Insel Rügen - Untersuchungsergebnisse und Anwendungsbereiche. - Petermanns Geographische Mitteilungen, 119: 261-269.

KLIEWE, H. \& JANKe, W. (1978): Zur Stratigraphie und Entwicklung des nordöstlichen Küstenraumes der DDR. - Petermanns Geographische Mitteilungen, 122/2: 81-91.

KLIEWE, H. \& JANKe, W. (1982): Der holozäne Wasserspiegelanstieg der Ostsee im nördlichen Küstengebiet der DDR. - Petermanns Geographische Mitteilungen, 126: 65-74.

KLIEWE, H. \& JANKe, W. (1991): Holozäner Küstenausgleich im südlichen Ostseegebiet bei besonderer Berücksichtigung der Boddenausgleichsküste Vorpommerns. - Petermanns Geographische Mitteilungen, 135: $1-15$.

LAMPE, R. (2005a): Late-glacial and Holocene water-level variations along the NE German

Baltic Sea coast - review and new results. - Quaternary International, 133/134: 121-136.

LAMPE, R. (2005b): Reliefgenese und Faziesdifferenzierung am mesolithischen Fundplatz von Lietzow-Buddelin auf Rügen. - Bodendenkmalpflege in Mecklenburg-Vorpommern. Jahrbuch 2004, 52: 185-195.

LAmpe, R. \& JAnke, W. (2004): The Holocene sea-level rise in the Southern Baltic as reflected in coastal peat sequences. - Polish Geological Institute Special Papers, 11: 19-30.

LEMKe, W. (1998): Sedimentation und paläogeographische Entwicklung im westlichen Ostseeraum (Mecklenburger Bucht bis Arkonabecken) vom Ende der Weichselvereisung bis zur Litorinatransgression. - 186 S.; Habilitationsschrift, Universität Greifswald,

Lemke, W., Jensen, J.B., Bennike, O., Endler, R., Witkowski, A. \& KuiJPERS, A. (2001): Hydrographic thresholds in the western Baltic Sea Late Quarternary geology and the Dana River concept. - Marine Geology, 176: 191-201.

LÜBKE, H. (2005): Vorbericht zu den Sondierungen submariner steinzeitlicher Fundstellen in den nördlichen Boddengewässern Rügens. - Bodendenkmalpflege in Mecklenburg-Vorpommern, Jahrbuch 2004, 52: 211-220.

Ministerium fÜr BAU, LANDESENTWicklung UND UMwelt MecklenBURG-VORPOMMERN (1994): Generalplan Küsten- und Hochwasserschutz Mecklenburg-Vorpommern. - 108 S.; Schwerin.

MöвUs, G. (2000): Geologie der Insel Hiddensee (südliche Ostsee) in Vergangenheit und Gegenwart - eine Monographie. - Greifswalder Geowissenschaftliche Beiträge, 8: 1-150.

NAumann, M. (2006): Faziesdifferenzierung und holozäne Küstenentwicklung der Halbinsel Bug /Rügen. - Thesis, Institut für Geographie und Geologie, Universität Greifswald, $83 \mathrm{~S}$.

PeAcock, J. D. (1993): Late quaternary marine mollusca as palaeoenvironmental proxies: A compilation and assessment of basic numerical data for NE Atlantic species found in shallow water. - Quaternary Science Reviews, 12: 263-275.

RössLER, D. (2006): Reconstruction of the Littorina Transgression in the Western Baltic Sea. - PhD thesis, Universität Greifswald, 135 S.

Roy, P. S., Cowell, P.J., Ferland, M.A. \& Thom, B.G. (1994): Wave-dominated coasts. - In: CARTER, R.W.G. \& Woodroffe, C.D. (eds): Coastal evolution - Late Quaternary shoreline morphodynamics: 121-186.

Schwarzer, K., Diesing, M. \& Trieschmann, B. (2000): Nearshore facies of the southern shore of the Baltic Ice Lake - example from Tromper Wiek (Rügen Island). - BALTICA, 13: 69-76.

SchÜTZE, H. (1931): Die Haken und Nehrungen der Außenküste von Rügen - Beiheft Jahrbuch der Pommerschen Geographischen Gesellschaft, 1931/32: 1-155.

Uscinowicz, S. (2006): A relative sea-level curve for the Polish Southern Baltic Sea. - Quaternary International, 145-146: 86-105. 